administration of serotonin to rats either decreases or increases granuloma formation, depending on the function of the adrenal gland (Bianchine and Eade, 1967). Excessive fibrosis appears only if adrenal insufficiency is induced. This raises the question of whether there might be adrenal insufficiency in patients who develop fibrotic syndromes in response to serotonin or methysergide. Possibly any drug which relies on a serotonin-simulating action for the treatment of migraine has the potential of producing excessive fibrosis in susceptible subjects.

We wish to thank Drs. J. D. Gillies and D. Burke and the neurological registrars who assisted us in the neurological clinic, and Miss A. M. Mackie and the staff of the pharmacy department for their willing collaboration. $\mathrm{BC105}$ and placebo tablets were supplied by Sandoz (Australia) Ltd., methdilazine by Mead Johnson Pty. Ltd., and Lysenyl (Spofa) by Boucher and Muir Pty. Ltd.

ADDENDUM.-BCl05 has now been given the generic name pizotifen and the proprietary name Sandomigran.

REFERENCES

Anthony, M., Hinterberger, H., and Lance, J. W. (1967). Archives of Neurology, 16, 544.

Anthony, M., Hinterberger, H., and Lance, J. W. (1969). In Research and Clinical Studies in Headache, vol. 2, edited by A. P. Friedman, p.29. Basel, Karger.
Anthony, M., and Lance, J. W. (1968). Medical fournal of Australia, 1, 56.

Bianchine, J. R., and Eade, N. R. (1967). Fournal of Experimental Medicine, 125, 501 .

Curran, D. A., Hinterberger, H., and Lance, J. W. (1965). Brain, 88, 997.

Curran, D. A., Hinterberger, H., and Lance, J. W. (1967). In Research and Clinical Studies in Headache, vol. 1, edited by A. P. Friedman, p.74. Basel, Karger.

Curran, D. A., and Lance, J. W. (1964). Fournal of Neurology, Neurosurgery and Psychiatry, 27, 463.

Dalessio, D. J., Camp, W. A., Goodell, H., and Wolff, H. G. (1961). Archives of Neurology, 4, 235.

De La Lande, I. S., Cannell, V. A., and Waterson, J. G. (1966). British fournal of Pharmacology and Chemotherapy, 28, 255.

Feher, P. H., and Kalz, F. (1966). Dermatologica. 133, 190.

Graham, J. R. (1967). American fournal of the Medical Sciences, 254, 23.

Graham, J. R. (1968). BC105 for prevention of migraine in patients previously taking methysergide. Headache Rounds, The Faulkner Hospital, 26 June.

Lance, J. W., and Anthony, M. (1968). Medical fournal of Australia, 1, 54.

Lance, J. W., Anthony, M., and Gonski, A. (1967). Archives of Neurology, 16, 553 .

Lish, P. M., Albert, J. R., Peters, E. L., and Allen, L. E. (1960). Archives Internationales de Pharmacodynamie et de Thérapie, 129,

Miller, J., and Fishman, A. (1961). Annals of Allergy, 19, 164.

Ryan, R. E. (1968). Headache, 8, 118.

Sicuteri, F. (1959). International Archives of Allergy and Applied Immunology, 15, 300.

Sicuteri, F., Franchi, G., and Del Bianco, P. L. (1967). International Archives of Allergy and Applied Immunology, 31, 78.

Sicuteri, F., Testi, A., and Anselmi, B. (1961). International Archives of Allergy and Applied Immunology, 19, 55.

\title{
Regional Lung Function in Patients with Obstructive Lung Diseases
}

\author{
DOMINIC GAZIANO,* ${ }^{*}$ M.D. ; ANTHONY SEATON, $†$ B.A., M.B., M.R.C.P. \\ COLIN OGILVIE, $\ddagger$ M.D., F.R.C.P.
}

British Medical fournal, 1970, 2, 330-333

\begin{abstract}
ummary: Regional lung function was measured, using $N$ radioactive xenon-133, in $a^{\circ}$ group of normal subjects and in three carefully defined groups of patients with obstructive lung disease. When compared with the normal subjects, patients in the emphysematous group showed a relative reduction of ventilation and perfusion to the upper zones, while patients having chronic bronchitis without cardiac or respiratory failure showed a predominantly lower zone defect. In the group of patients with chronic bronchitis with cardiac and respiratory failure no consistent pattern was found.
\end{abstract}

\section{Introduction}

Patients with obstructive lung diseases (chronic bronchitis or emphysema) have a wide range of abnormalities in regional lung function, but these have not been related to clinical or physiological types (Bentivoglio et al., 1963; Hugh-Jones et al., 1966; Pain et al., 1967). In most of these studies the disturbance of ventilation and perfusion was maximal in the lower parts of the lung. Conversely the morbid anatomical changes of both centrilobular and panacinar emphysema are predominant in the upper parts of the lung (Heard, 1959; Heppleston and Leopold, 1961). Earlier studies in this laboratory (Ogilvie and Catterall, 1959; Ogilvie, 1967) showed that bullae arising from the lower lobes were more often associated with chronic bronchitis, than those arising from the upper lobes. This evidence from previous published work suggested that regional abnormalities might be predominant in the lower parts of the lung in chronic bronchitis and in the upper parts in emphysema. In order to test this hypothesis we studied regional lung function with radioactive xenon-133 in three carefully

* Research Fellow from the University of West Virginia, Morgantown, U.S.A.

† Senior Medical Registrar.

$\ddagger$ Consultant Physician

Cardiothoracic Surgical Centre, Broadgreen Hospital, Liverpool 14 selected groups of patients with obstructive lung disorders, comparing the results with those obtained in normal subjects.

\section{Subjects}

The normal subjects were volunteers from among the hospital staff. None had any history of respiratory disease and all had normal chest radiographs. The patients all had physiological evidence of airways obstruction as defined by a forced expiratory volume in one second (F.E.V.1) of less than $60 \%$ of the forced vital capacity. They were divided into three groups: group 1, five patients with type $A$ or emphysematous obstructive lung disease; group 2, seven patients with type B or bronchitic obstructive lung disease associated with respiratory failure and cor pulmonale; and group 3, six patients with chronic bronchitis as defined by daily sputum production for more than three months of each year, but without respiratory failure or cor pulmonale.

The criteria for dividing the patients into type $\mathrm{A}$ and type B obstructive lung disease are essentially those of Fletcher et al., 1963, 1964. The criteria are listed in Table I, and the values for individual patients in each group are given in Table II. For admission to either group six of the seven criteria had to be fulfilled.

\begin{tabular}{|c|c|c|}
\hline & Type A & Type B \\
\hline 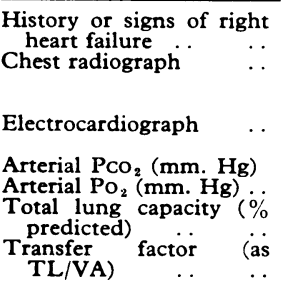 & $\begin{array}{l}\text { Absent } \\
\text { Normal heart size. } \\
\text { Peripheral vascular } \\
\text { attenuation } \\
\text { No right ventricular } \\
\text { hypertrophy } \\
\text { Under } 45 \\
\text { Over } 70 \\
\text { Over } 110 \% \\
\text { Under } 3.5\end{array}$ & $\begin{array}{l}\text { Present } \\
\text { Cardiac enlargement. In- } \\
\text { flammatory lung changes } \\
\text { only } \\
\text { Right ventricular hyper- } \\
\text { trophy } \\
\text { Over } 45 \\
\text { Under } 70 \\
\text { Under } 110 \% \\
\text { Over } 3.5\end{array}$ \\
\hline
\end{tabular}


TABLE II

\begin{tabular}{|c|c|c|c|c|c|c|c|c|c|c|c|}
\hline $\begin{array}{l}\text { Case } \\
\text { No. }\end{array}$ & Age & Sex & $\begin{array}{c}\text { History or } \\
\text { Signs of R.H.F. }\end{array}$ & $\begin{array}{c}\text { Chest } \\
\text { Radiographs }\end{array}$ & Electrocardiogram & F.V.C. (1) & $\frac{\text { F.E.V.1 }}{\text { F.V.C. }} \times 100$ & $\underset{(\mathrm{mm} . \mathrm{Hg})}{\mathrm{PcO}_{\mathbf{3}}}$ & $\begin{array}{c}\mathrm{Po}_{\mathbf{2}} \\
(\mathrm{mm} . \mathrm{Hg})\end{array}$ & $\frac{\text { T.L.C. }}{\text { Predicted T.L.C. }} \times 100$ & $\begin{array}{l}\text { Transfer } \\
\text { Factor } \\
\text { TL/VA }\end{array}$ \\
\hline $\begin{array}{l}1 \\
2 \\
3 \\
4 \\
5 \\
\end{array}$ & $\begin{array}{l}57 \\
52 \\
55 \\
60 \\
55\end{array}$ & $\begin{array}{l}M . \\
M . \\
M . \\
M . \\
M\end{array}$ & $\begin{array}{l}\text { No } \\
\text { No } \\
\text { No } \\
\text { No } \\
\text { No } \\
\end{array}$ & $\begin{array}{l}\text { Emphysema } \\
\text { Emphysema } \\
\text { Emphysema } \\
\text { Emphysema } \\
\text { Emphysema } \\
\end{array}$ & $\begin{array}{c}\text { Normal } \\
\text { Normal } \\
\text { Normal } \\
\text { Left bundle-branch block } \\
\text { Normal }\end{array}$ & $\begin{array}{c}\text { Type } A \\
2.60 \\
1.80 \\
1.80 \\
2.50 \\
1.20 \\
\end{array}$ & $\begin{array}{l}29 \\
40 \\
46 \\
34 \\
29 \\
\end{array}$ & $\begin{array}{l}41 \\
45 \\
40 \\
42 \\
55\end{array}$ & $\begin{array}{l}80 \\
74 \\
72 \\
80 \\
71 \\
\end{array}$ & $\begin{array}{r}140 \\
110 \\
119 \\
95 \\
112 \\
\end{array}$ & $\begin{array}{l}2 \cdot 8 \\
1.9 \\
2 \cdot 3 \\
2 \cdot 9 \\
1 \cdot 25 \\
\end{array}$ \\
\hline Mean & 56 & & & & & $2 \cdot 00$ & 35 & 44 & 75 & 115 & $2 \cdot 2$ \\
\hline 6 & 67 & M. & Yes & R.V.H. P.A. & R.V.H. & $\begin{array}{c}\text { Type } B \\
2.05\end{array}$ & 38 & 48 & 64 & 100 & $5 \cdot 0$ \\
\hline 7 & 63 & M. & Yes & R.V.H. Basal & R.V.H. & 1.95 & 26 & 58 & 61 & 115 & 3.5 \\
\hline 8 & 35 & M. & Yes & $\begin{array}{l}\text { changes } \\
\text { R.V.H. P.A. }\end{array}$ & R.A.D. R.V.H. & $2 \cdot 65$ & 36 & 62 & 63 & 113 & $4 \cdot 1$ \\
\hline 9 & 51 & M. & Yes & R.V.H. P.A. & R.V.H. & $1 \cdot 30$ & 54 & 55 & 48 & 75 & $4 \cdot 0$ \\
\hline 10 & 42 & M. & Yes & $\begin{array}{l}\text { R.V.H. P.A. } \\
\text { prominence }\end{array}$ & R.A.D. R.V.H. & $1 \cdot 70$ & 35 & 57 & 43 & 78 & $2 \cdot 9$ \\
\hline 11 & 59 & M. & Yes & $\begin{array}{l}\text { R.V.H. P.A. } \\
\text { prominence }\end{array}$ & R.A.D. R.V.H. & $2 \cdot 65$ & 45 & 57 & 40 & 91 & $4 \cdot 2$ \\
\hline 12 & 52 & F. & Yes & $\begin{array}{l}\text { R.V.H. Basal } \\
\text { inflammatory } \\
\text { changes }\end{array}$ & R.A.D. R.V.H. & $1 \cdot 10$ & 50 & 62 & 42 & 66 & - \\
\hline Mean & 52 & & & & & 1.91 & 40 & 56 & 51 & 91 & 3.9 \\
\hline $\begin{array}{l}13 \\
14 \\
15 \\
16 \\
17 \\
18 \\
\end{array}$ & $\begin{array}{l}60 \\
50 \\
47 \\
55 \\
43 \\
51 \\
\end{array}$ & $\begin{array}{l}\text { M. } \\
M . \\
M . \\
M . \\
M . \\
M .\end{array}$ & $\begin{array}{l}\text { No } \\
\text { No } \\
\text { No } \\
\text { No } \\
\text { No } \\
\text { No } \\
\end{array}$ & $\begin{array}{l}\text { Normal } \\
\text { Normal } \\
\text { Normal } \\
\text { Normal } \\
\text { Normal } \\
\text { Normal } \\
\end{array}$ & $\begin{array}{l}\text { Normal } \\
\text { Normal } \\
\text { Normal } \\
\text { Normal } \\
\text { Normal } \\
\text { Normal } \\
\end{array}$ & $\begin{array}{l}\text { Chronic } \\
2 \cdot 10 \\
2 \cdot 45 \\
3 \cdot 70 \\
3 \cdot 70 \\
2 \cdot 60 \\
2 \cdot 70 \\
\end{array}$ & $\begin{array}{c}\text { Bronchitis } \\
53 \\
41 \\
58 \\
39 \\
31 \\
50 \\
\end{array}$ & $\begin{array}{l}32 \\
40 \\
36 \\
40 \\
42 \\
37 \\
\end{array}$ & $\begin{array}{l}90 \\
68 \\
69 \\
60 \\
62 \\
64 \\
\end{array}$ & $\begin{array}{r}105 \\
89 \\
92 \\
113 \\
108 \\
110 \\
\end{array}$ & $\begin{array}{l}5 \cdot 0 \\
5 \cdot 1 \\
4 \cdot 1 \\
5 \cdot 2 \\
8 \cdot 0 \\
6 \cdot 4 \\
\end{array}$ \\
\hline Mean & 51 & & & & & $2 \cdot 88$ & 45 & 38 & 69 & 103 & $5 \cdot 6$ \\
\hline
\end{tabular}

The vital capacity and F.E.V.1 were measured on a Pulmometer (Godart). Residual volume was obtained by the helium dilution technique (Bates and Christie, 1950) and the transfer factor for carbon monoxide by the single breath method of Ogilvie et al. (1957). Arterial $\mathrm{Po}_{2}$ and $\mathrm{PCO}_{2}$ were measured with an E.I.L. Bishop electrode and a Severinghaus electrode, respectively.

For regional lung function studies xenon-133 was used and the subjects were studied in the supine position. The scanning device consisted of paired counters mounted on a stand recently designed in this laboratory (Brown et al., 1969). The counters were fitted with focused slit collimators (West, 1966b) and the gamma radiation was detected by sodium iodide crystals. Each lung was scanned by anterior and posterior counters, and the counts for these two were added and recorded on ultraviolet light sensitive paper. Scans were performed while the patient held his breath after a slow maximal inspiration, using the procedure described by Dollery and Gillam (1963). Three basic scans were made: the first, after an inhalation of xenon, displayed regional ventilation; the second, after equilibration of the lungs with a xenon-air mixture, displayed regional lung volume; and the third, after an intravenous injection of xenon solution, displayed regional lung perfusion. It should be noted that the regional distribution of a single inspiration reflects only one facet of ventilation - that is, the ratio of inspiratory capacity to total lung capacity. For the sake of simplicity, and in keeping with the practice of other workers in this field, we have used the term "ventilation" throughout this paper rather than I.C./T.L.C. ratio.

Indices for the distribution of ventilation and perfusion per unit alveolar volume were calculated at $2-\mathrm{cm}$. intervals up each lung according to the formula of West (1966a). The I $\mathbf{B}$ perfusion index is given by $\underset{E}{-} \times \frac{A}{A} \times 100$. I and $E$ are the

regional count rates after injection and equilibration, respectively, while A and B are the amounts of radioactivity in the lung after injection and equilibration, respectively. A represents the millicuries of xenon injected and $B$ is obtained by multiplying the total lung capacity by the concentration of xenon (in millicuries per litre) in the spirometer circuit after $\mathrm{V} \quad \mathrm{B}$

rebreathing. The ventilation index is given by $-\times-\times 100$; $\mathrm{A}^{1}$ is calculated by multiplying the concentration of xenon in the spirometer by the inspired volume minus the anatomical and instrument dead space. $V$ is the regional count rate of xenon after inspiration. These indices should approximate $100 \%$, if all parts of the lungs are evenly perfused and ventilated.

For the purpose of expressing our results $21 \mathrm{~cm}$. of lung below the second intercostal space has been divided into three $7-\mathrm{cm}$. regions, subsequently referred to as upper, middle, and lower zones. The distribution indices for each zone have been averaged and expressed as a percentage of the mean distribution index for the whole lung. Even distribution would, therefore, be represented by the figure one in each zone.

\section{Results}

The results in normal subjects are shown in Fig. 1. Distribution of ventilation is even, while perfusion shows a slight apparent increase towards the upper zone. The results in patients with type A obstructive lung disease are given in Fig. 2. There is a reduction of perfusion in the upper zone and a more pronounced reduction of ventilation in this region. These results compared with the normal subjects are significantly different at the $5 \%$ level for perfusion and at the $1 \%$ level for ventilation. The findings in patients with type $B$ obstructive lung disease are shown in Fig. 3. There are pronounced regional abnormalities but with considerable variability between patients, and no consistent pattern of distribution in relation to the upper and lower zones occurred. In patients with chronic bronchitis without respiratory failure or cor pulmonale (Fig. 4) there is an apparent diversion of both perfusion and ventilation from the lower to the upper zones, the difference from normal subjects at the lower zones being significant at the $5 \%$ level for perfusion and at the $1 \%$ level for ventilation. 

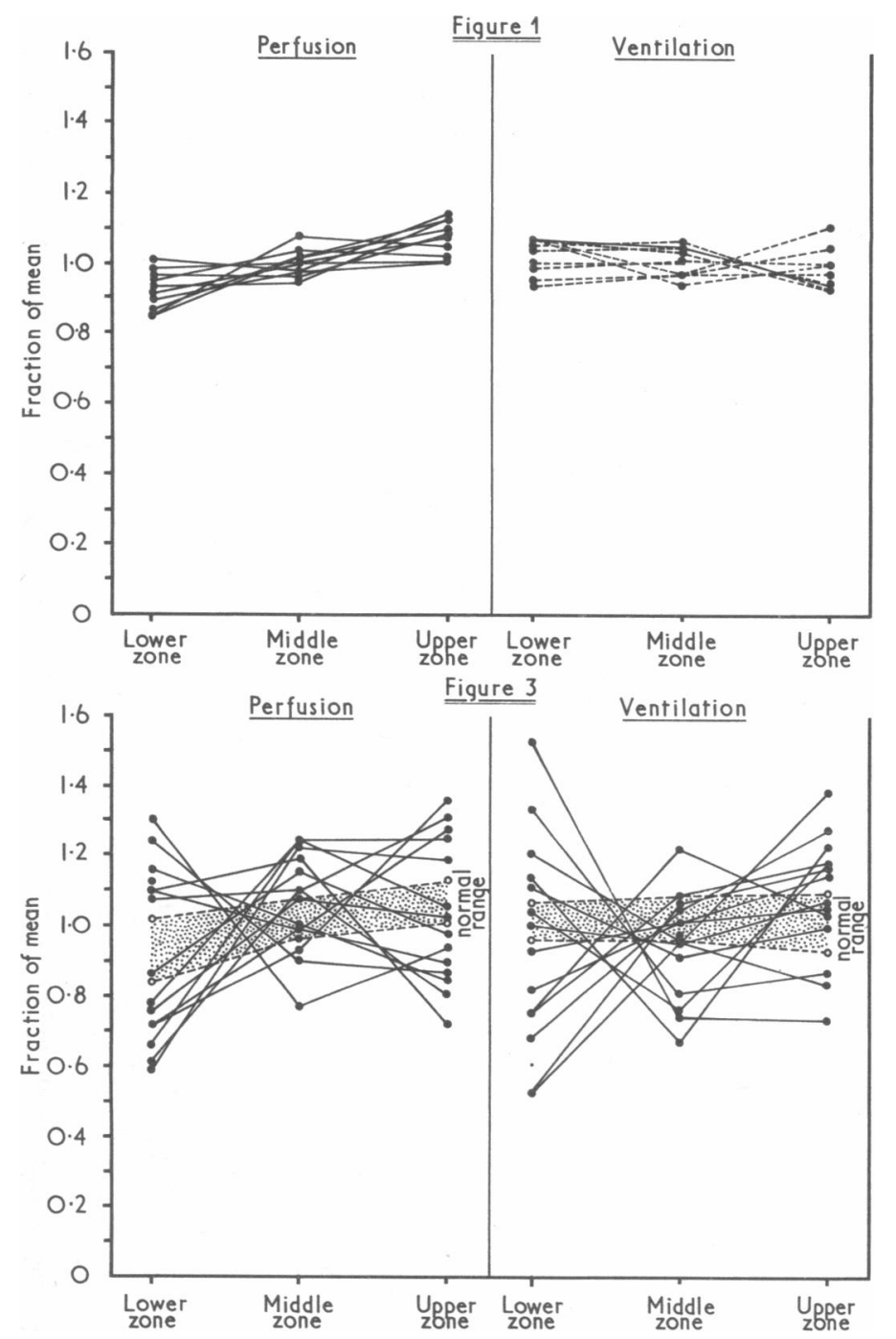

\section{Discussion}

The clinical-pathological correlation studies of Burrows et al. (1966) and of Mitchell et al. (1964) have shown a greater incidence of emphysema among those patients with type A obstructive lung disease than among those with type B disease. Furthermore, other workers (Laws and Heard, 1962; Reid and Millard, 1964) found a good correlation between the radiological and pathological signs of emphysema.

No previous attempt has been made to study regional lung function in patients with clearly defined types of obstructive lung disease. In the report of Bentivoglio et al. (1963), however, the patients with bilateral upper zone abnormalities were those with the largest functional residual capacities, the lowest transfer factor, and relatively little disturbance blood gases; in other words, they tended to conform to the physiological criteria for type A patients.

Our present results in the type A group are in keeping with the pathological finding of emphysema as a disease predominantly affecting the upper parts of the lungs It should be noted, however, that these results indicate a relative decrease in function of the upper zones and do not necessarily exclude disease in other parts. An explanation for this zonal distribution of emphysema has been offered by Heppleston (1968), who suggested that the decreased alveolar perfusion and increased size of alveoli in the upper zones might play a part in alveolar disruption. West (1966b) suggested that the increased transpulmonary pressure in the upper zones might predispose to alveolar destruction.
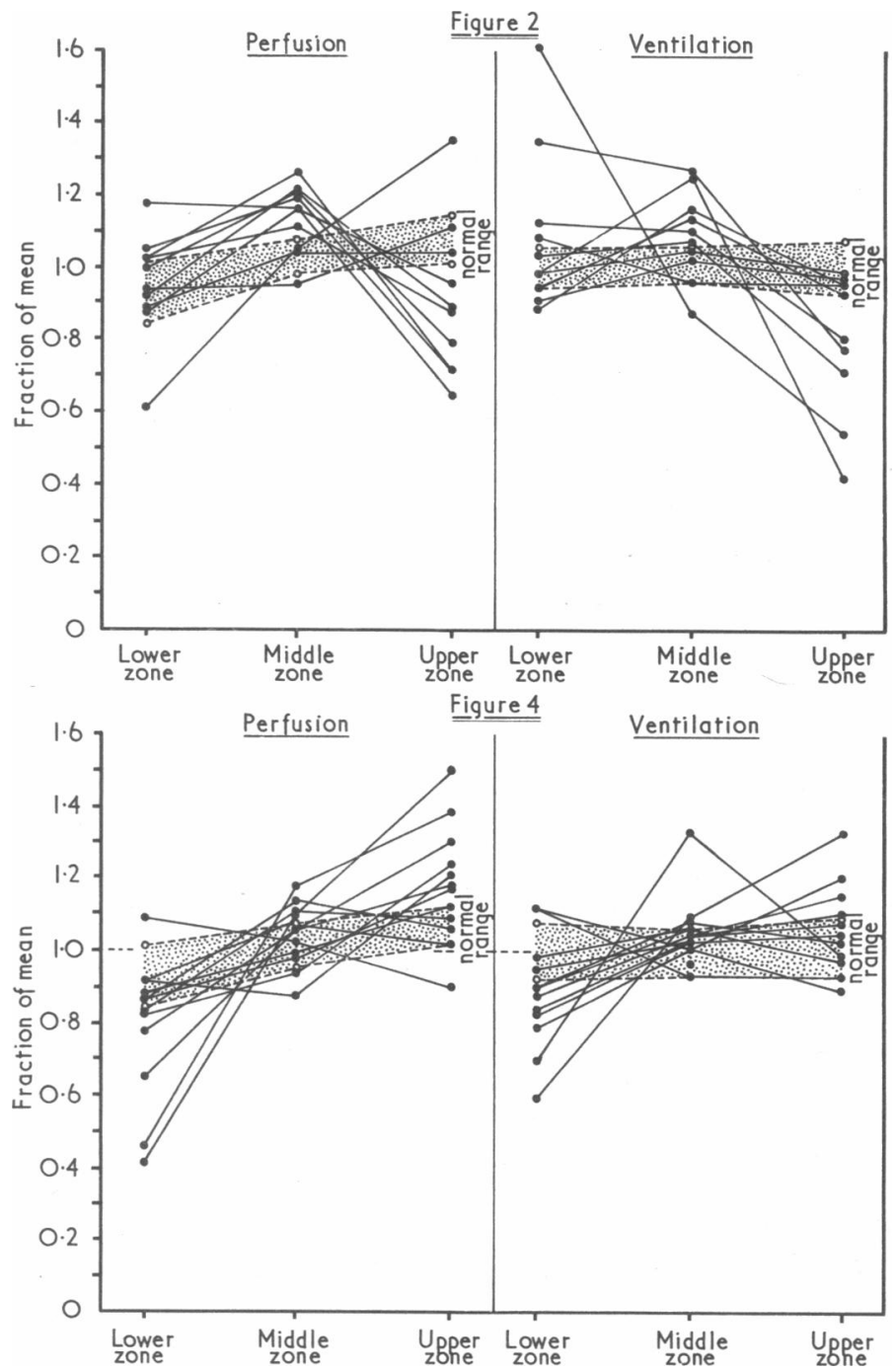

Our findings of a predominantly basal defect in simple chronic bronchitis has been described before (Anthonisen et al., 1968). One possible explanation for this finding is that smoke and other air pollutants may exert their main impact on the lower parts of the lung. Some support for this is provided by Milic-Emili et al. (1966), who showed that when a subject breathes from functional residual capacity in the upright position a major portion of ventilation occurs in the lower zones. Equally important may be the impaired airway clearing mechanism which has been found in patients with bronchitis (Mitchell et al., 1966). The ciliated pseudostratified columnar epithelium which propels a blanket of mucus to the oropharynx is replaced in bronchitis by metaplastic squamous epithelium with thickened basement membrane. Retained secretions will therefore tend to gravitate and narrow the dependent air passages.

The lack of a consistent pattern of regional abnormality among patients with chronic bronchitis and cor pulmonale was not wholly unexpected. Some patients in this group may well have had a degree of emphysema undetected in the radiograph. Alternatively it may be that if the basal defect of early bronchitis is due to preferential ventilation of this area with damage resulting from inhaled irritants, then as ventilation is diverted to healthy parts with less airways resistance these too will sustain similar damage.

We are indebted to Dr. W. A. Littler, Dr. R. S. Ledward, Miss S. Williams, Mrs. M. Deakin, and Miss Y. Golden for technical help. 


\section{REFERENCES}

Anthonisen, N. R., Bass, H., Oriel, A., Place, R. E. G., and Bates, D. V. (1968). Clinical Science, 35, 495.

Bates, D. V., and Christie, R. V. (1950). Clinical Science, 9, 17

Bentivoglio, L. G. et al. (1963). American Review of Respiratory Diseases, 88, 315 .

Brown, I. K., Kirk, F., and Seaton, A. (1969). British fournal of Radiology, 42, 545 .

Burrows, B., Fletcher, C. M., Heard, B. E., Jones, N. L., and Wootliff, J. S. (1966). Lancet, 1, 830.

Dollery, C. T., and Gillam, P. M. S. (1963). Thorax, 18, 316.

Fletcher, C. M., Hugh-Jones, P., McNicol, M. W., and Pride, N. B. (1963). Quarterly fournal of Medicine, 32, 33.

Fletcher, C. M., Jones, N. L., Burrows, B., and Niden, A. H. (1964). American Review of Respiratory Diseases, 90, 1 .

Heard, B. E. (1959). Thorax, 14, 58.

Heppleston. A. G., (1968) In Form and Function in the Human Lung, edited by G. Cumming and L. B. Hunt, p. 18. Edinburgh, Livingstone.

Heppleston, A. G., and Leopold, J. G. (1961). American fournal of Medicine, 31, 279.
Hugh-Jones, P., Ritchie, B. C., and Dollery, C. T. (1966). British Medical fournal, 1, 1133

Laws, J. W., and Heard, B. E. (1962). British fournal of Radiology, 35,

Milic-Emili, J., Henderson, J. A. M., Dolovich, M. B., Trop, D., and Kaneko, K. (1966). Fournal of Applied Physiology, 21, 749.

Mitchell, R. S., Ryan, S. F., Petty, T. L., and Filley, G. F. (1966) American Review of Respiratory Diseases, 93, 720.

Mitchell, R. S., Vincent, T. N., Ryan, S., and Filley, G. F. (1964) American fournal of the Medical Sciences, 247, 513.

Ogilvie, C. (1967). Thorax, 22, 286.

Ogilvie, C., and Catterall, M. (1959). Thorax, 14, 216.

Ogilvie, C. M., Forster, R. E., Blakemore, W. S., and Morton, J. W. (1957). Fournal of Clinical Investigation, 36, 1.

Pain, M. C. F., Glazier, J. B., Simon, H., and West, J. B. (1967) Thorax, 22, 453.

Reid, L., and Millard, F. J. C. (1964). Clinical Radiology, 15, 307.

West, J. B. (1966a). In Ciba Foundation. Symposium Development of the Lung, edited by A. V. S. de Reuk and R. Porter, p. 176. London, Churchill.

West. J. B. (1966b). The Use of Radioactive Materials in the Study of Lung Function. Amersham, Radiochemical Centre.

\title{
Use of a One-man, Mobile Pressure Chamber in the Treatment of Carbon Monoxide Poisoning
}

\author{
J. N. NORMAN, ${ }^{*}$ M.D., PH.D., F.R.C.S.; J. MACINTYRE, $\dagger$ M.B., CH.B.; J. R. SHEARER, $\ddagger$ M.B., CH.B.
}

G. SMITH, $囚$ M.D., CH.M., F.R.C.S.

British Medical fournal, 1970, 2, 333-334

Cummary: For the past five years a mobile pressure chamber has been used to treat patients suffering from severe carbon monoxide poisoning with oxygen at 2 atmospheres pressure. Of the 25 patients treated, 20 recovered completely and only three died. This apparatus could also be used for hyperbaric oxygen therapy in other conditions for which it is indicated.

\section{Introduction}

It was shown by Haldane (1895) that carbon monoxide is not itself toxic and that its lethal effects are produced purely by blocking haemoglobin and causing anoxia. Though the action of carbon monoxide in the body has subsequently been shown to be rather less simple, it is still generally agreed that the fundamental aim in the treatment of carbon monoxide poisoning is the same as that of any other anoxic lesionnamely, to cut short the anoxia (Marriott, 1955a, 1955b). In carbon monoxide anoxaemia it is important that the blood should be rid of carbon monoxide by the most rapid and efficient means possible since undue delay in restoring tissue oxygenation may result in brain damage, particularly of the extrapyramidal system. In routine practice this is achieved by the administration of $5 \% \mathrm{CO}_{2}$ in oxygen (Killick and Marchant, 1959; Douglas et al., 1961; Norman, Douglas, and Smith, 1966). It has, however, been known for many years that if ogygen at 2 atmospheres pressure is breathed in carbon monoxide poisoning then carbon monoxide is removed from the blood much more rapidly than when carbon dioxide/oxygen mixtures are breathed at atmospheric pressure. (End and Long, 1942; Pitts and Pace, 1949; Douglas et al., 1962). When a patient breathes oxygen at 2 atmospheres pressure the extra oxygen dissolved in the plasma bypasses the blocked haemoglobin and immediately corrects the state of tissue hypoxia. Thus the benefit of using hyperbaric oxygen in carbon monoxide poisoning is twofold, the rapid dissociation of carboxyhaemoglobin being secondary to the immediate correction of tissue hypoxia.

The use of oxygen at 2 atmospheres pressure in resuscita-

* Senior Lecturer in Surgery.

†Registrar in Surgery.

$\ddagger$ Research Fellow in Surgery.

§Regius Professor of Surgery.

gDepartment of Surgery, University of Aberdeen, Aberdeen AB9 2ZD. tion from carbon monoxide poisoning has been shown to be an efficient means of therapy (Smith and Sharp, 1960; Smith, Ledingham, Sharp, Norman, and Bates, 1962; Norman and Ledingham, 1967), but this facility is available only to those who live within easy access of a hyperbaric unit, and there are few of these units. Smith (1962) suggested the use of an inexpensive, mobile, hyperbaric chamber which could if necessary be taken to the patient in an ambulance or which could be used in centres where large hyperbaric units were not available.

This report deals with our experience during the past five years in the treatment of those cases of severe carbon monoxide poisoning which occurred in the Aberdeen area. A moderately priced, mobile pressure chamber designed by ourselves in association with Normalair Ltd. was used throughout.

\section{Procedure}

Patients suffering from carbon monoxide poisoning who were unconscious on admission to the casualty department of Aberdeen Royal Infirmary were transferred to the hyperbaric unit for treatment. After initial assessment, which included a brief examination of the cardiorespiratory and nervous systems and the removal of a specimen of venous blood for the measurement of the carboxyhaemoglobin concentration, an endotracheal tube was passed, the patient was placed within the mobile pressure chamber (see Fig.), and the pressure was raised to 2 atmospheres absolute with oxygen. By this means the patient was given oxygen at 2 atmospheres pressure to breathe until consciousness returned or until two hours had elapsed. The chamber was then decompressed, and after further clinical examination the patient was transferred to the receiving medical unit, where oxygen at atmospheric pressure was breathed for a further few hours.

Carbon monoxide poisoning has become a less popular method of suicide and most of our cases were accidental, occurring in the older age groups of patients, often living alone and with co-existing atherosclerosis and dimmed senses. Of the 25 patients treated six were aged under 60,13 were 60 to 80 , and six were over 80 . Twenty of the 25 patients recovered completely. Two had residual neurological signs and in these cases a cerebral vascular accident may have preceded the gassing. Of the three patients 